\title{
РОЛЬ НІМЕЦЬКОМОВНИХ ЛЕКСИЧНИХ ЗАПОЗИЧЕНЬ У СИСТЕМІ МОВИ-РЕЦЕПТОРА
}

Колесник М. Ю. Роль німецькомовних лексичних запозичень у системі мови-рецептора. Проаналізовано проблему адаптації німецькомовних лексичних запозичень у системі мови-рецептора, а також простежено шляхи проникнення іншомовних слів в українську мову та подальше їх освоєння.

Ключові слова: іншомовна лексика, запозичення, метафора. 
Колесник М. Ю. Роль немецкоязычных лексических заимствований в системе языка-рецептора.

Проанализирована проблема адаптации немецких лексических заимствований в систему языка-рецептора, а также прослежены пути проникновение иноязычных слов в украинский язык и дальнейшее их освоение.

Ключевые слова: иноязычная лексика, заимствования, метафора.

Kolesnik M. Y. The Problem of German Lexical Borrowings Adaptation in the System of Language-Recipient.

The article deals with the problem of German lexical borrowings adaptation in the system of language-recipient, the ways of foreign words penetration into the Ukrainian language as well as their assimilation.

Keywords: foreign-language vocabulary, borrowings, metaphor.

Лексичні запозичення, як відомо, є одним з способів поповнення словникового складу будь-якої мови протягом усієї історії іiі існування. Загальновідомим $є$ те, що запозичена лексика у складі сучасної української мови посідає значне місце й сягає своїм корінням у далеке минуле. Німецькі лексичні запозичення не є винятком.

На сучасному етапі розвитку українського мовознавства принципового значення набуває питання про вироблення й удосконалення принципів та засад мовної політики, зокрема тих положень, що стосуються іншомовних запозичень. Усебічний аналіз іншомовного слова, з'ясування доцільності та перспективності чи взагалі недоцільності його функціювання в мові й мовленні неможливі без звернення до мовленнєвої компетенції носіїв мови. Такий напрям наукового дослідження проблеми освоєння іншомовних лексичних запозичень є важливим і актуальним.

У мовознавстві проблема збагачення мови іншомовними словами розглядається в багатьох дослідженнях. Серед них слід виокремити роботи Ю. Жлуктенка, О. Муромцевої, Л. Крисіна. Зокрема, освоєння іншомовних запозичень у наукових терміносистемах досліджують О. Лисенко; питання словотвірного освоєння запозичень є об’єктом уваги С. Рижикової, Л. Чурсіної, Д. Мазурик; О. Стишов і О. Тодор розглядають запозичення слів як ефективний сучасний спосіб збагачування лексичного складу мови.

Основна мета статті - розглянути та дослідити способи перекладу німецькомовних лексичних запозичень українською мовою.

Одне 3 найважливіших місць у роботах лінгвістів посідає проблема адаптації запозичень у системі мови-рецептора. Л. Чурсіна у праці «Словотвірна валентність основ французького походження в сучасній українській літературній мові» підкреслює, що освоєння лексики іншомовного походження відбувається на різних рівнях - графічному, фонетичному, морфологічному, лексико-семантичному та словотвірному. Вона зазначає, що центром словотвірного аналізу $\epsilon$ не похідне слово і не словотвірна 
модель, а твірна основа та їі іманентна властивість сполучуватися 3 певним набором афіксів, інших дериваційних компонентів.

О. Муромцева в роботі «Розвиток лексики української літературної мови в другій половині XIX - на поч. XX ст.» пояснює це тим, що пристосування граматичної форми відбувається швидшими темпами, воно тісніше пов'язано з відношеннями в межах національної морфологічної і словотвірної системи [6]. До того ж саме для української мови надзвичайно важливою була роль російської мови як мови посередника: 3 огляду на матеріальну спільність морфологічних засобів обох мов засвоєння запозичень українською мовою відбувалося значно швидше і з меншою кількістю варіантів, ніж це спостерігалося при їх звуковому засвоєнні. Варіанти, що йшли із Західної України, були локальними, ненормативними, чужими для граматичної системи української мови [6].

У статті В.Скачкової «Деякі наслідки семантичного освоєння німецькомовних лексичних запозичень», зазначено: якщо розподілити німецькомовний лексичний матеріал, який входить до складу сучасної української літературної мови, на групи з позиції семантичних змін, то чітко вимальовуються дві значні групи слів. До першої з них увійдуть ті лексичні запозичення, які в мові-рецепторі функціонують у тому семантичному обсязі, що й у мові-джерелі. Причому йдеться як про однозначні, так і багатозначні лексеми. До другої групи увійдуть слова, які в українській мові набули семантичних зрушень, а саме: а) запозичення, що зменшили кількість значень порівняно з кількістю значень у німецькій мові; б) лексеми, які збільшили кількість значень щодо кількості значень етимону [9].

Автор розглядає кожну 3 груп окремо на предмет визначення наслідків семантичних процесів, які відбуваються 3 німецькомовною лексикою під час освоєння українською мовою.

Першу групу німецькомовних лексичних запозичень становлять лексеми, які, як було зазначено, в українській мові існують у тому семантичному обсязі, що й у мові-джерелі. Щодо моносемічної лексики, то це найчастіше лексика термінологічна - як вузькоспеціального (наукового), так і ширшого (побутового) характеру. Здебільшого, це назви реалій, що належать до військової, технічної, промислової, наукової і побутової сфер: колонтитул, станіоль, смальта, вашгерд, дюкер, вісмут, иніцель, cmpayc, пудель, іниухm ma ін. Наявна також абстрактна лексика: ерзац, зумер, цугцванг. Найчастіше запозичена лексика не є однозначною. Отже, другу групу слів, запозичених українською мовою в семантичному обсязі, який вони мали в німецькій мові, становлять багатозначні слова. Вони належать до військової, технічної, промислової, будівельної, медичної, спортивної галузей: флянецьь, кронцииркуль, візир, шліи, квартирмейстер, капсула, матриця, ордер, бункер, итатив, корнцанг, трензель, шприц, иротт, шнур та інші [8].

() М. Ю. Колесник, 2013. 
Слід відзначити, що не завжди німецькомовне багатозначне слово приходило в українську мову з усією сукупністю значень. Деякі слова запозичені в одному з значень, пізніше до цього значення приєднувалися інші, притаманні етимону. Так, слово шнур на першому етапі запозичування з'явилося у значенні «тонка мотузка». Пізніше воно запозичує з німецької мови значення «міра довжини, що відповідає приблизно 45 м», яке на сьогодні застаріло. На наступних етапах функціонування в мові лексема шнур паралельно набуває, як у мові-джерелі, так і в мові, що запозичує, переносного значення «низка чого-небудь», наприклад, коралів, перлів. 3 розвитком електротехніки названа лексема знову-таки розширює семантичний обсяг паралельно в обох мовах, набуває змісту «електричний дріт із кількох ізольованих проводів».

До другої групи належать ті запозичення, які змінили свій семантичний обсяг у новому мовному оточенні. Серед них виокремлюємо значну кількість слів, що звузили в мові-рецепторі свій семантичний обсяг. Причому більшість запозичень, які існують в українській мові зі скороченим семантичним обсягом, проникла до нас в одному з вузьких обмежених значень, що в мові-джерелі розвинулося внаслідок відмежування від ширшого, загального значення.

Таким $є$ вживання слова штиб у значення «кам'яновугільне пилоподібне паливо», що в німецькій мові виступає як вторинне, більш вузьке, порівняно з його основним значенням «пил» і «прах» / нім. Staub. Подібних прикладів можна навести безліч. Це лексеми юнга, абшит, плаи, дека, иуг, флінт, итрих, глет, люфт, блінт та ін.

В. Скачкова зафіксувала також ряд німецькомовних лексем, які розширили свій семантичний обсяг в українській мові. Аналізуючи їх, ми дійшли висновку, що розширення семантичного обсягу відбувалося різними шляхами. Найтиповіші з них це: а) перенесення за функціями, наслідком чого часто є перехід з однієї термінологічної сфери в іншу, 3 вузькоспеціальної до загальновживаної лексики і навпаки; б) метафоризація; в) метонімічне перенесення; г) поширення власних назв на назви реалій [9].

Прикладом запозичення, що розширило свій семантичний обсяг шляхом перенесення за функціями, можуть служити лексеми командир, штаб, які функціонують в німецькій мові у сфері військової справи. Проникнувши в українську мову 3 цими значеннями, вони значно розширили свій семантичний обсяг, стали фактично загальновживаними (порівняємо: командир будівельного загону, або «вона в нашій сім’ї за командира»; штаб трудових справ, штаб будівельного загону тощо).

Спостерігається також зворотнє явище, а саме: термінологізація загальновживаної запозиченої лексики. Так, унаслідок перенесення за функціями запозичення кабінет, фартух, футляр перейшли з побутової у спеціальні сфери, набувши значення термінів у різних галузях життя. 
Лексема кабінет прийшла свого часу в українську мову у значенні «робоча кімната». У сучасній німецькій мові це слово зазнало метонімічного перенесення, і його вживають у значенні «кабінет міністрів», а для поняття «робоча кімната» існує німецьке Arbeitszimmer. Значення ж «кабінет міністрів» розвивалося й у мові-рецепторі. Але, крім цих значень, лексема кабінет набула подальшого семантичного розвитку. Просторове іiї значення було перенесено і в інші сфери: кабінет лікаря / Sprechzimmer /, кабінет для занять / нім. Fachzimmer /, кабінет начальника / нім. Chefzimmer. Отже, з побутової сфери, у яку лексему кабінет було запозичено спочатку, вона перейшла шляхом перенесення за функціями у сфери медицини, освіти, у виробничу галузь.

Як приклад розширення семантичного обсягу шляхом метафоризації автор подає лексеми флокени, калібр, зигзаг, илейф, фраєр та ін. Так, запозичення фраєр / нім. Freier - «жених» / існувало у значенні етимона в XIX - на початку XX століття на території Західної України. Проте 3 часом воно було переосмислене й функціонує в сучасній українській мові зі зневажливо-насмішкуватим відтінком як метафора зі значенням «пустий, нікчемний чоловік». Менш поширене, ніж метафора (проте трапляється серед німецькомовних запозичень), метонімічне перенесення. Як приклад автор наводить лексему верстат, що означає в мові-джерелі / нім. - Werstatt / «майстерня, цех», а в сучасній українській мові переосмислена зі значенням «верстат» [9].

Існують німецькі лексичні запозичення в сучасній українській мові у сфері рослинного і тваринного світу. Ця лексика становить понад сорок одиниць і передбачає назви квітів, дерев, кущів, культурних рослин, різновидів грибів тощо: айстра, бавовна, барвінок, букс, вайда, гіацинт, едельвейс, імбир, квасоля, кольрабі, померанець, рапс, спаржа (ипараги, шпаргаль), тмин (кмин), трюфель, цибуля, шпинат; назви птахів та інших представників тваринного світу: вальдщнеп, гаршнеп, доберман, какаду, каплун, кроншнеп, мопс, пудель, страус, такса [10].

Більшість запозичень належить до активного складу сучасної української мови (70\%). Словами обмеженого вживання є 30\% запозичень, як-от: лакрищя, люфа, фінвал, мангольд, тамаринд, які характерні для мови фахівців. Трапляються й діалектні варіанти, як, наприклад, карп, дупель, гайстер, каплун, що наявні у вжитку населення окремих областей України [10].

Отже, розглянувши літературу з цієї теми, можна зробити висновок, що німецькі запозичення мали великий вплив на розвиток української літературної мови. Науковці зазначають, що лексичні запозичення є одним з способів поповнення словникового складу будь-якої мови протягом усієї історії іiі існування. Безпосередні контакти із закордоном, вивчення західноєвропейських мов, безумовно, сприяли проникненню іншомовних слів в українську мову й подальшому їх освоєнню. На XIX - початок (с) М. Ю. Колесник, 2013. 
ХХ століття припадає найбільш інтенсивне збагачення словникового складу української літературної мови запозиченою лексикою: за відносно короткий історичний період в українську літературну мову ввійшли i утвердилися в ній найважливіші слова міжнародного характеру на позначення основних понять політики, науки, літератури, мистецтва.

\section{Література}

1. Биржакова Е. Е. История лексикологии русского языка XVIII ст. Языковые контакты и заимствования / Е. Е. Биржакова, Л. Л. Войнова, Л. Л. Кутина. - Л. : Наука, 1972. - 430 c.

2. Височина В. А. Німецькі слова в українській мові / В. А. Височина, Н. А. Семенова // Дослідження з граматики і граматичної стилістики української мови : зб. наук. праць. - Дніпропетровськ : ДДУ, 1986. - С. $79-85$.

3. Гринев С. В. Терминологические заимствования / С. В. Гринев // Вопросы заимствования и упорядочения иноязычных терминов и терминоэлементов. - М., 1982. - C. 108-135.

4. Зиндер Л. Р. Современный немецкий язык / Л. Р. Зиндер. - Л., 1941. - 319 с.

5. Крысин Л. П. Иноязычные слова в современном русском языке / Л. П. Крысин. M., 1968. -207 c.

6. Муромцева О. Г. Розвиток лексики української літературної мови в другій половині XIX - на поч. XX ст. / О. Г. Муромцева. - Х. : Вища школа, 1985. - С. 66-103.

7. Пилинський М. М. Мовна норма і стиль / М. М Пилинський. - К. : Наукова думка, 1976. - С. 287.

8. Скачкова В. В. Лексика німецького походження в українській художній літературі на воєнну тематику / В. В. Скачкова // Мовознавство. - 1989. - № 6. - С. 55-57.

9. Скачкова В. В. Деякі наслідки семантичного засвоєння німецьких лексичних запозичень / В. В. Скачкова // Лінгвістичні дослідження : зб. наук. праць лінгвістичних кафедр ХДПУ імені Г. С. Сковороди. - Х. : Слово, 1992. - С. 86-89. 